\title{
Effectiveness of protection of seagrass (Posidonia oceanica) populations in Cabrera National Park (Spain)
}

\author{
NÚRIA MARBÀ ${ }^{*}$, CARLOS M. DUARTE ${ }^{1}$, MARIANNE HOLMER ${ }^{2}$, REGINO MARTÍNEZ $^{1}$, \\ GOTZON BASTERRETXEA ${ }^{1}$, ALEJANDRO ORFILA ${ }^{1}$, ANTONI JORDI ${ }^{1}$ AND JOAQUÍN \\ TINTORÉ1 \\ ${ }^{1} I M E D E A$ (CSIC-UIB), Grup d'Oceanografia Interdisciplinar, Institut Mediterrani d'Estudis Avançats, Carrer Miquel Marquès 21,07190 \\ Esporles (Illes Balears), Spain and ${ }^{2}$ Institute of Biology, SDU-Odense University, Campusvej 55, DK-5230 Odense M, Denmark \\ Date submitted: 7 November 2001 Date accepted: 3 July 2002
}

\section{SUMMARY}

Posidonia oceanica, the dominant seagrass species in the Mediterranean, appears to be experiencing widespread loss. Efforts to conserve Posidonia oceanica are increasing, as reflected in the increase in the number of marine protected areas in the Mediterranean. However, the effectiveness of these measures to conserve seagrass meadows is unknown. In this study, the present status of the Posidonia oceanica meadows in the Cabrera National Park (Mediterranean), the only marine national park in Spain, was assessed, and the effectiveness of the conservation measures adopted was tested. This was done by reconstruction of past and present growth, quantification of the demographic status of the established meadows, and quantification of patch formation and growth rates in areas where recolonization is occurring. The meadows extended from 1-43 $\mathrm{m}$ deep at Santa Maria bay and from $1-33 \mathrm{~m}$ at Es Port. Leaf production rate of the stands examined ranged between 6.5 and 7.8 leaves shoot $^{-1} \mathrm{yr}^{-1}$, with higher rates in Santa Maria than in Es Port. Vertical rhizomes elongated at rates ranging from $5.39-10.12 \mathrm{~mm} \mathrm{yr}^{-1}$, annual vertical growth in Santa Maria stands being larger than that in the stands developing at Es Port. Horizontal rhizomes elongated slowly (from $2.6-6.1 \mathrm{~cm} \mathrm{yr}^{-1}$ ), and branching was sparse $\left(<0.25\right.$ branches $\mathrm{yr}^{-1}$ axis $\left.^{-1}\right)$, with maximum elongation and branching rates in areas where patches were actively colonizing. Flowering was a rare event in all the stands $(<0.015$ flowers shoot $^{-1} \mathrm{yr}^{-1}$ ). Patch formation and patch growth rates in active colonizing areas were slow, but they increased after implementation of mooring regulations in the Park. Similarly, the leaf production tended to increase, and vertical rhizome growth to decrease, in both bays following the onset of regulation measures. However, the decrease in vertical growth detected was greater at Santa Maria, where access is prohibited to visitors, than at Es Port, where boats are

* Correspondence: Dr Núria Marbà Tel: +34 971611729 Fax: +34 971611761 e-mail: ieanmb@clust.uib.es allowed to moor, attached to permanent weights. Shoot mortality rate was generally low (mean $0.10 \pm$ $0.02 \mathrm{ln}$ units $\mathrm{yr}^{-1}$ ) but exceeded the recruitment rate $\left(<0.009\right.$ and $0.17 \mathrm{ln}$ units $\left.\mathrm{yr}^{-1}\right)$ in $55 \%$ of the meadows examined, indicative of negative net population growth rates. Regulation of mooring activities has improved the status of the $P$. oceanica meadows at Cabrera National Park. The demographic analysis, however, indicated that while $P$. oceanica meadows at Santa Maria are in good shape, those at Es Port seem to be compromised. The observed differences in meadow status reflect the large differences in circulation inside the bays (water residence time at Santa Maria $=4$ days, water residence time at Es Port $=11$ days) and the anthropogenic pressure both bays support.

Keymords: Posidonia oceanica, growth, flowering, demography, colonization, water residence time

\section{INTRODUCTION}

Posidonia oceanica is the dominant seagrass species in the Mediterranean Sea, where it covers about $50000 \mathrm{~km}^{2}$ (Bethoux \& Copin-Móntegut 1986), developing key ecosystems affecting biological production and biogeochemical processes in the Mediterranean littoral (see Bethoux \& Copin-Móntegut 1986). P. oceanica appears to be experiencing a widespread loss in the Mediterranean (Peirano \& Bianchi 1995; Marbà et al. 1996), derived from both anthropogenic impacts and large-scale change (Delgado et al. 1997; Marbà \& Duarte 1997; Cancemi et al. 2000). These losses cannot be mitigated in the short term, since colonization of $P$. oceanica meadows takes centuries (Duarte 1995), due to the very slow growth $\left(2 \mathrm{~cm} \mathrm{yr}^{-1}\right.$; Marbà \& Duarte 1998) and very sparse sexual reproduction (Meinesz \& Lefèvre 1984; Buia \& Mazzella 1991) of this species.

Efforts to conserve Posidonia oceanica are increasing, as reflected in the increase in Mediterranean marine protected areas (MPAs), which presently number 122 (UNEP [United Nations Environment Programme] 1999). The European Agenda 21 programme involves the European Union member states protecting up to $12.2 \%$ of the territory, which 
largely comprise $P$. oceanica meadows in the Mediterranean countries. While the effectiveness of MPAs to conserve fish fauna has been often demonstrated (Garcia-Rubies \& Zabala 1990; Francour 1994), their effectiveness to conserve seagrass meadows remains untested. Whereas MPAs can effectively exclude proximal sources of stress to seagrass (such as anchor damage and sewage inputs), the widespread loss of $P$. oceanica appears to involve diffuse impacts, such as the tendency towards erosion derived from sea-level rise (see Marbà \& Duarte 1997; Duarte 2002).

Posidonia oceanica, as any seagrass, is a rhizomatous plant with a highly organized growth pattern, which is based on the reiteration of modules (leaves, rhizome internodes, roots and inflorescences). This architecture allows quantification of growth and shoot population dynamics of $P$. oceanica meadows during the lifespan of the shoots (up to 30 years) from single visits using dating techniques (Duarte et al. 1994; Marbà et al. 1996). Moreover, the length of the vertical rhizome internodes is sensitive to seasonal forcing and sediment accretion, as their length varies depending on the time of the year when they were produced and sedimentation rate (Marbà \& Duarte 1997). The sensitivity of the plant to seasonal forcing and sediment accretion allows the identification of events of burial or erosion, as deviations from the mean length of the internodes, during the lifespan of the shoots (Marbà \& Duarte 1997). In addition, the peduncle of $P$. oceanica inflorescences remains attached to the vertical rhizome node where it was produced, thereby providing a record of past flowering events along the lifespan of the shoots (Pergent \& Pergent-Martini 1990).

Here we assess the distribution and present status of the $P$. oceanica meadows in Cabrera National Park (Western Mediterranean), the only marine national park in Spain. We do so by retrospectively quantifying the past plant growth dynamics and the demographic status of the established meadows in two bays with contrasting levels of protection (Es Port Bay and Santa Maria Bay), as well as by quantifying the patch formation and growth rates in areas where recolonization is occurring. This assessment also helped to evaluate the effectiveness of the conservation measures adopted since 1993 (i.e. regulation of the daily number of visitors, restriction of public areas and exclusion of military activity), and, in particular, to test whether the status of the stands is compromised at Es Port Bay due to anthropogenic stresses, such as sewage from visitors, which are absent from the neighbouring Santa María Bay. We then examine, on the basis of the examination of the circulation and anthropogenic pressure inside both bays where the largest meadows of $P$. oceanica occur, the reasons for the differences in status revealed by the results.

\section{METHODS}

\section{Study site}

The Cabrera Archipelago comprises 19 islands, from small islets to the $38.6 \mathrm{~km}$ perimeter Cabrera Island, located $9 \mathrm{~km}$ south-east of Mallorca Island (Fig. 1). Cabrera Island has been inhabited since $1100 \mathrm{BC}$ and was deforested in the early
(A)

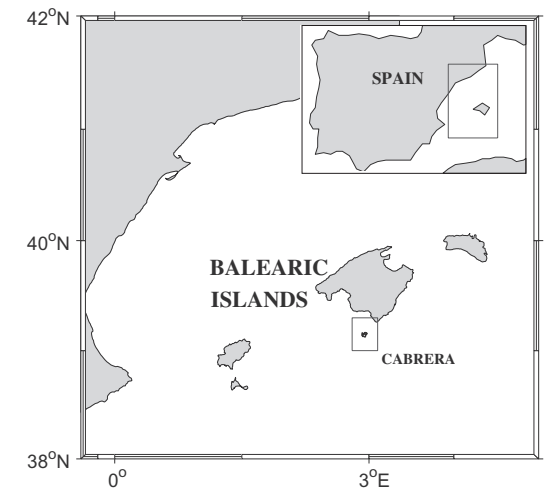

(B)

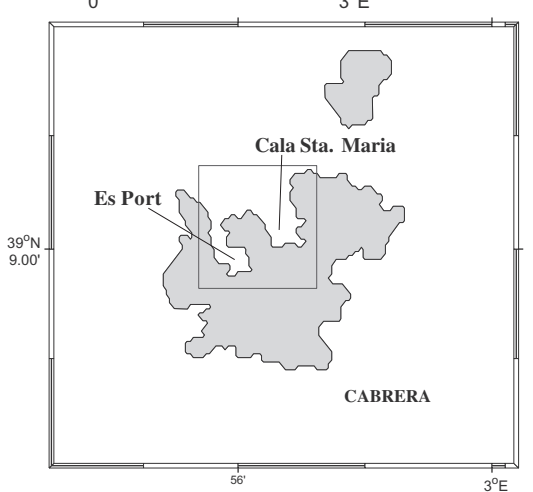

(C)

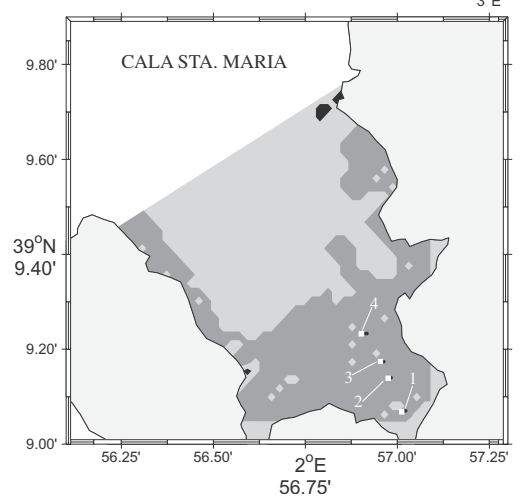

(D)

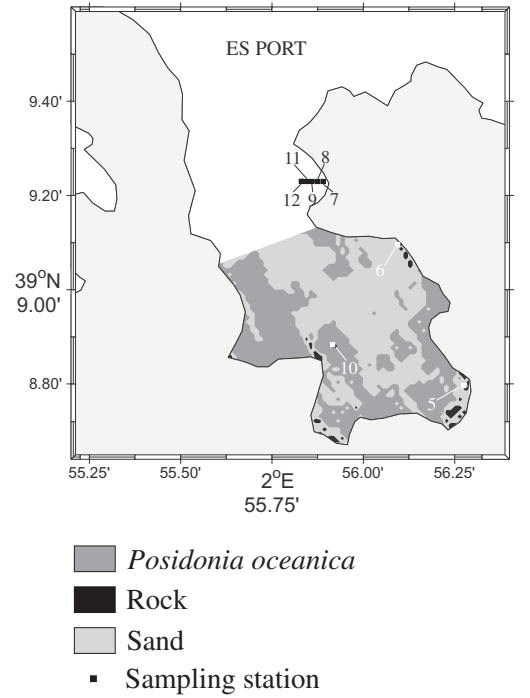

Figure 1 Location of Cabrera National Park, and extension of Posidonia oceanica meadows in Santa Maria Bay and Es Port Bay. Seafloor covered by sand and rock is also shown. The sampling sites (stations) are indicated by numbers. 
19th century (Frontera et al. 1993.). The Archipelago became an army station in 1940, with a small group of soldiers stationed there, and was subsequently declared a national park in 1991, when conservation policies were implemented to protect both the land and marine components.

Posidonia oceanica meadows have been reported to extend from about $1 \mathrm{~m}$ to about $37 \mathrm{~m}$ depth in the clear waters of Cabrera Island (mean light attenuation coefficient $0.063 \mathrm{~m}^{-1}$; Ballesteros \& Zabala 1993). The largest meadows occur in the Santa Maria Bay, followed by that in the bay known as Es Port de Cabrera. They grow, in both bays, on carbonate-rich sediment $(87-97 \%$ carbonates, M. Holmer et al., unpublished data 2000 ) with very low iron content (Fe II $<5 \mu \mathrm{M}, \mathrm{M}$. Holmer $e t$ al., unpublished data 2000). Es Port is a sheltered Bay traditionally used as a natural harbour (Fig. 1), and presently hosting the Park's visitor centre and services. While Santa Maria Bay has been closed to visitors, except scientists, since 1993, Es Port receives up to 380 visitors per day in summer, accessing the Park through a ferry service, and the occupants of up to 50 ships, about 200 persons in total being allowed to moor in Es Port Bay on any one day. Mooring of the ships has not represented a direct mechanical impact to the underlying $P$. oceanica meadows since 1993, when a set of 50 fixed mooring points were deployed to prevent anchoring on $P$. oceanica meadows and to limit the number of boats present at anyone time. In addition, destructive military activities, which sporadically destroyed the shallow areas of the meadow, were discontinued. Most of the sewage produced by visitors in moored ships, few of which are equipped with holding tanks, is discharged raw into the Es Port waters. Moreover, the Es Port waters also receive the outflow of the treated sewage produced by the visitors on land (Cabrera National Park, unpublished data 1999).

The sediment properties at Santa Maria and Es Port Bays reflect the differences in anthropogenic pressure to which they are subject. The total sediment reducible-sulphur concentration and sediment sulphate-reduction rate at Es Port Bay are $500 \%$ and $40 \%$ higher than those at Santa Maria Bay (M. Holmer et al., unpublished data 2000), and sedimentation rates are $50 \%$ greater at Es Port Bay than at Santa Maria Bay (M. Holmer et al., unpublished data 2000).

\section{Assessment of seagrass}

The Posidonia oceanica meadows growing in Santa Maria and Es Port Bays were mapped in December 2000, using acoustic records obtained through a ship-mounted Biosonics DE4000 echosounder with a $200 \mathrm{kHz}$ transducer. The first/second bottom echo ratio technique was applied to identify the different bottom typologies, relying on estimating the hardness signature by taking the integral of the squared echo envelope of the second bottom echo $(E 2)$ and the roughness signature derived from the integral of the second part of the first bottom echo (E1) (Orlowski 1984; Chivers et al. 1990). The resulting data were filtered, averaged ( 1 output equals 20 pings average) and clustered in three groups (Posidonia meadows, sandy and rocky bottoms) (a)

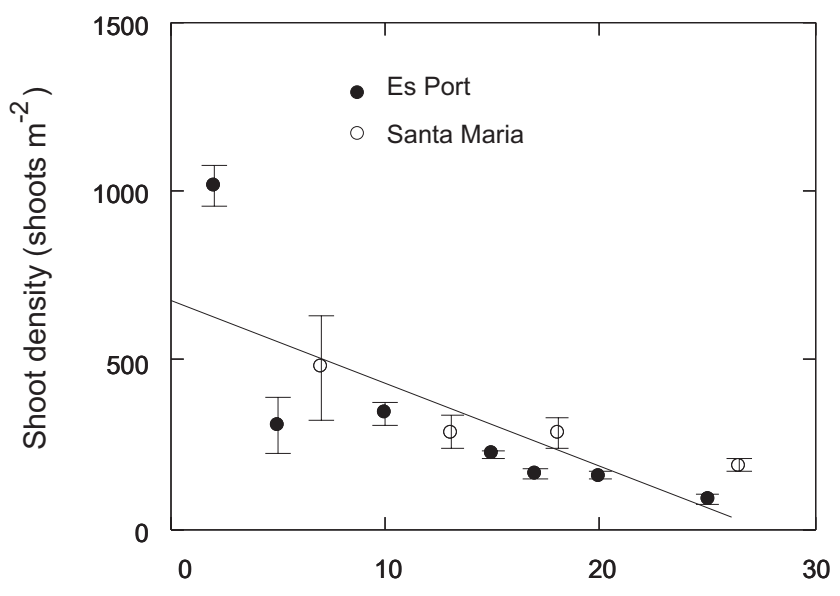

(b)

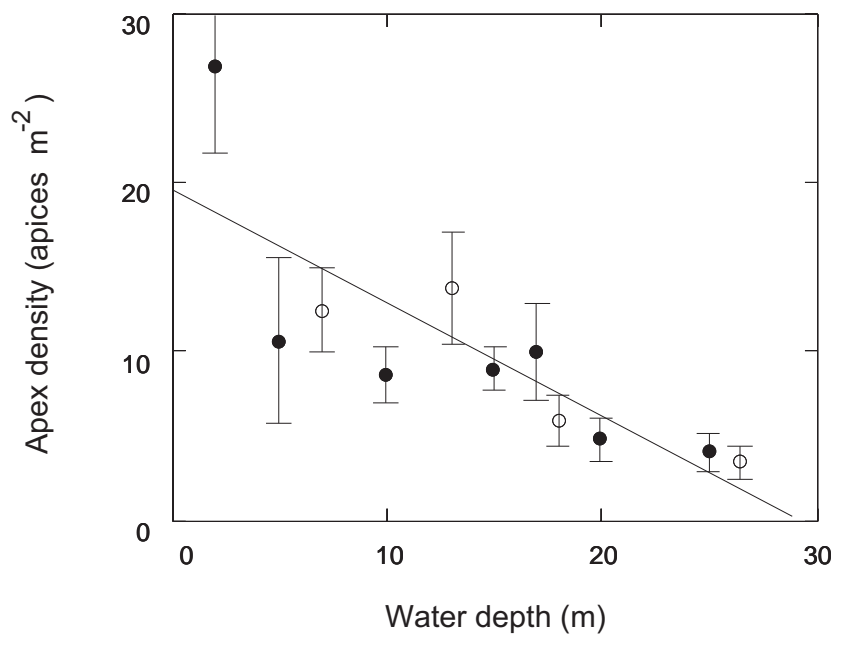

Figure 2 Relationships between (a) mean shoot density (shoots $\mathrm{m}^{-2}$ ), and $(b)$ mean apex density (apices $\mathrm{m}^{-2}$ ), and water depth in the Posidonia oceanica meadows studied. Bars represent the standard error of the mean. See the Results for the fitted regression equations.

through calibrations performed on known bottom types in the same area.

During autumn and winter 2000, the status of $P$. oceanica populations was examined at four stations along a depth gradient (7-26.5 m depth) in Santa María Bay, and eight stations in Es Port (Fig. 2). The eight Es Port stations were: five stations along a depth gradient $(5-25 \mathrm{~m})$, one adjacent to a mooring weight (17 m depth), one adjacent to the beach ( $4 \mathrm{~m}$ depth), and one in an area with active patch dynamics near the pier ( $2 \mathrm{~m}$ depth). At each station two $20 \mathrm{~m}$ transects were laid and apex and shoot density measured every second and fourth metre, respectively, using $0.25 \mathrm{~m}^{2}$ quadrats. In addition, 100 to $200 P$. oceanica shoots were carefully harvested at each station in order to maintain their connection to the horizontal rhizomes. The plant material was transported to the laboratory, where the number and length of horizontal rhizome internodes in between two consecutive 
shoots were measured, the total number of horizontal rhizome internodes and branches were counted, the age of all shoots harvested was estimated, the flowering events imprinted on vertical rhizomes were recorded, and the sequences of vertical internode length for the 3-5 oldest shoots in each sample were measured under a dissecting microscope. These measurements provided estimates of the number of leaves annually produced by a shoot, vertical and horizontal rhizome elongation rates, horizontal rhizome branching rate, flowering frequency and the age structure of the shoot population.

The average number of leaves annually produced per shoot in each population was estimated from the seasonal variability in vertical internodal length. Identification of annual cycles in the length of vertical internodes, requires short-term and interannual variability to be filtered out to emphasize the seasonal signal (Duarte et al. 1994; Short \& Duarte 2001). Therefore, we applied a high- and low-frequency filter to each raw data series (i.e. running averages of $30 \%$ and $150 \%$ of the expected number of internodes contained in a cycle). We then subtracted the low-frequency filtered series (i.e. the interannual component of vertical internodal length variability) from the high-frequency filtered series, to extract the seasonal trend of vertical internode length. Because of the 1:1 relationship between leaf and vertical internode formation, the number of vertical internodes between two consecutive minima equalled the number of leaves produced that year by a short shoot (Duarte et al. 1994). Knowledge of the mean number of leaves produced annually per shoot in each meadow during the shoot lifespan allowed calculation of the annual mean leaf plastochron interval (PI, the time elapsed between the formation of two consecutive leaves; Erickson \& Michelini 1957), and the translation of time in plastochron intervals units to chronological time (i.e. days or years). The elongation rate of vertical rhizomes for different years was assessed as the vertical rhizome length between the two consecutive shortest internodes identified on the sequences of vertical internode length.

The rate of formation of horizontal rhizome internodes was estimated by regressing the number of horizontal internodes between pairs of shoots connected by a horizontal rhizome piece against their age difference (Duarte et al. 1994). The slope of the fitted regression equation represented the mean number of horizontal rhizome internodes produced per leaf PI. The product of this slope by the mean length of a horizontal rhizome internode and the mean number of leaves produced annually per shoot provided an estimate of the mean annual horizontal rhizome elongation rate (Duarte et al. 1994). Because the annual leaf formation rate was not estimated for Station 6, the mean leaf formation rate estimated for the other sites at Es Port, which were relatively homogeneous, was used to calculate annual horizontal rhizome extension at Station 6 (Fig. 1).

The horizontal branching rate $(H B R$, in branches internode $\mathrm{e}^{-1}$ ) was calculated as,

$$
H B R=\left(\frac{N u m b e r \text { of branches in the sample }}{\text { Number of horizontal internodes in the sample }}\right)
$$

We multiplied the horizontal branching rate in branches internode ${ }^{-1}$ by the number of horizontal internodes produced by an axis per year to calculate the annual horizontal branching rate (branches $\mathrm{yr}^{-1}$ axis $^{-1}$ ).

Flowering intensity ( $F I$, in inflorescences shoot ${ }^{-1}$ leaf $\left.\mathrm{PI}^{-1}\right)$ was estimated as,

$F I=$

$\left(\frac{\text { Total number of inflorescence peduncles in the sample }}{\text { Total number of leaves produced by the sample }}\right)$

We multiplied the flowering intensity (as inflorescences leaf $\mathrm{PI}^{-1}$ ) by the inverse of leaf PI (in years) to calculate flowering intensity as inflorescences shoot ${ }^{-1} \mathrm{yr}^{-1}$. Moreover, the flowering intensity of $P$. oceanica for particular years was estimated as the per cent of flowering events observed in one year relative to the total amount of living shoots in the sample that year.

The population dynamics of the meadow were characterized by the age distribution of living shoots, and shoot recruitment, shoot mortality and net population growth rates. Shoot age $\left(\mathrm{Age}_{\text {shoot }}\right.$, in days) was estimated as,

Age $_{\text {shoot }}=(N S t L+N L S c)$ leaf PI

where $N S t L$ was the number of standing leaves of the shoot and $N L S c$ the number of leaf scars on the vertical rhizome supporting the shoot. Shoot mortality rate $\left(M, \mathrm{yr}^{-1}\right)$ was derived from the exponential decline in the number of living shoots $\left(N_{0}\right)$ with time $(t$, in PIs) as,

$N_{t}=N_{0} \cdot e^{-M \cdot t}$

where $N_{0}$ is the number of shoots with age equal to the mode, and $N_{t}$ is the number of shoots older than the modal age at time $t$. $M$ was estimated using a semi-logarithmic linear regression model, where constant mortality over shoot age classes and years was assumed. The annual gross shoot recruitment rate $\left(R_{\text {gross }}, \mathrm{yr}^{-1}\right)$ was calculated following Peterson and Fourqurean (2001) as,

$R_{\text {gross }}=\frac{\sum_{j=1}^{k} e^{\left(\ln n_{j}+M t_{j}\right)}}{N}$

where $n$ is the number of living shoots in the $j$ th age class, $t$ is the age of the $j$ th age class, $k$ is the oldest age class $<1 \mathrm{yr}$ old, $M$ is the per caput mortality rate, and $N$ is the total number of living shoots in all age classes. The ratio between recruitment and mortality rates $(R / M)$ was used to indicate whether populations were expanding (i.e. $R / M>1$ ), declining (i.e. $R / M<1$ ) or in steady state (i.e. $R / M=1$; Duarte \& SandJensen 1990; Duarte et al. 1994).

In addition, patch dynamics were investigated at the shallowest Es Port site, where a patchy Posidonia oceanica extended over an area of about 0.8 ha. The size (as area) 
of all Posidonia oceanica patches within this area was estimated from measurements of the two major orthogonal axes of the patches done in situ by scuba divers by approximation to an ellipsoid. Then, the radius of the equivalent circular area for each patch was calculated and used to represent the characteristic linear dimension of the patch. Patch age was estimated by dividing patch radius by annual rhizome elongation rate at that site. Patch age estimates, therefore, assumed constant rhizome growth rate and no patch area losses during patch life and represent, therefore, minimum estimates of the true patch age. The net increase in the vegetation cover since the oldest patch present was formed was calculated as the percentage of the available area covered by the patches for each year. Net temporal changes in density of patches were assessed as the cumulative increase in the number of patches with decreasing patch age (i.e. with increasing chronological time). These estimates represent the net rate of colonization in the area, which is expected to be lower than the gross rate of colonization, since patch mortality must have occurred during the colonization process.

\section{Statistical analysis}

Analysis of variance (ANOVA) was used to statistically test for differences between the $P$. oceanica populations studied. The effectiveness of $P$. oceanica protection in the Cabrera Archipelago was evaluated by using t-tests to compare leaf production, flowering intensity and vertical elongation rate, proxies of growth conditions and sedimentation rate (Marbà \& Duarte 1997), before and after implementation of conservation policies. The degree of correlation between variables was quantified with Pearson correlation coefficients.

Water residence time in Santa Maria and Es Port bays was estimated with a numerical model using finite element solution of the three-dimensional shallow water equations with conventional hydrostatic and Boussinesq approximations and eddy viscosity closure in the vertical, as described in Lynch and Werner (1987).

\section{RESULTS}

\section{Seagrass status}

The Posidonia oceanica meadows extended between $1 \mathrm{~m}$ and $43 \mathrm{~m}$ deep at Santa Maria Bay and between $1 \mathrm{~m}$ and $33 \mathrm{~m}$ at Es Port (Table 1). The calculated water residence times under the most common wind conditions (i.e. $u=-1 \mathrm{~m} \mathrm{~s}^{-1}$, $v=5 \mathrm{~m} \mathrm{~s}^{-1}$, module $5 \mathrm{~m} \mathrm{~s}^{-1}$, and direction $348^{\circ}$ ) were about 11 days for Es Port and 4 days for the larger basin of Santa Maria. P. oceanica covered $41.7 \%$ of the bottom of Santa Maria Bay and $35.5 \%$ of the bottom of Es Port Bay (Table 1; Fig. 1). Shoot density varied $>20$-fold among the sites (Table 2), and it declined significantly with increasing depth as described by the regression equation,

Shoot density $\left(\right.$ shoots $\left.\mathrm{m}^{-2}\right)=$ $674-24.4( \pm 6.9)$ water depth $(\mathrm{m})$

$\left(r^{2}=0.53, n=11, p<0.01\right)$

following a similar pattern in both bays (Fig. 2a). The density of rhizome apices also varied about ten-fold (Table 2; Fig. $2 b$ ), and declined with depth in addition, as described by the fitted regression equation,

Apex density $\left(\right.$ apices $\left.\mathrm{m}^{-2}\right)=$

$19.5-0.67( \pm 0.16)$ water depth $(\mathrm{m})$

$\left(r^{2}=0.61, n=11, p<0.005\right)$

The density of rhizome apices was strongly correlated with that of shoots $(r=0.91, p<0.01)$, with the apices representing, on average, $3.4 \pm 0.4 \%$ of the shoots.

The average leaf production rate was relatively uniform among stands (Table 2). Vertical growth varied among stands, ranging from $5.4 \mathrm{~mm}_{\text {year }}{ }^{-1}$ to $10.1 \mathrm{~mm}_{\text {year }}{ }^{-1}$ (Table 2). Annual vertical growth in Santa Maria stands tended to be larger than that in the stands developing at Es Port. The vertical rhizome growth significantly $(r=-0.74, p<0.05)$ declined with increasing depth, except for the shallowest stand at Es Port (Table 2). The horizontal rhizome growth was slow, ranging from $2.6-6.1 \mathrm{~cm} \mathrm{yr}^{-1}$, and it was significantly faster (t-test, $p<0.05)$ at the area where patches were

Table 1 Extent of sea floor and percentage of Posidonia oceanica cover (mean \pm SE) at different depth intervals in Santa Maria and Es Port Bays at Cabrera Island. Surface planar, P. oceanica maximum depth limit and \% cover for both bays are also provided.

\begin{tabular}{|c|c|c|c|c|c|c|c|c|}
\hline \multirow[t]{2}{*}{ Water depth (m) } & \multicolumn{2}{|c|}{ Surface $\left(\mathrm{m}^{2}\right)$} & \multicolumn{2}{|c|}{ \% Posidonia oceanica } & \multicolumn{2}{|c|}{$\%$ Sand } & \multicolumn{2}{|c|}{ \% Rock } \\
\hline & Santa Maria & Es Port & Santa Maria & Es Port & Santa Maria & Es Port & Santa Maria & Es Port \\
\hline $0-10$ & 165418 & 178400 & $89.1 \pm 3.9$ & $47 \pm 3$ & $10.5 \pm 3.8$ & $47.9 \pm 3$ & $0.4 \pm 0.8$ & $4.4 \pm 1.2$ \\
\hline $10-20$ & 133589 & 179467 & $86.2 \pm 2.3$ & $36.9 \pm 1.9$ & $12.2 \pm 2.2$ & $63.0 \pm 1.9$ & $1.5 \pm 0.8$ & $0.1 \pm 0.1$ \\
\hline $20-30$ & 177270 & 135903 & $62.4 \pm 2.1$ & $40.9 \pm 2.3$ & $36.3 \pm 2.1$ & $50.1 \pm 2.3$ & $1.3 \pm 0.5$ & 0 \\
\hline $30-40$ & 190294 & 86568 & $13 \pm 1.3$ & $9.6 \pm 1.6$ & $86.1 \pm 1.3$ & $90.4 \pm 1.6$ & $0.9 \pm 0.3$ & 0 \\
\hline $40-50$ & 163589 & 22157 & $6.9 \pm 0.9$ & & $93.1 \pm 0.9$ & 100 & 0 & 0 \\
\hline $50-60$ & 117866 & & & & 100 & & 0 & \\
\hline$>60$ & 31515 & & & & 100 & & 0 & \\
\hline Total & 979541 & 602495 & 41.8 & 35.5 & 57.5 & 60.9 & 0.7 & 1.3 \\
\hline
\end{tabular}


Table 2 Average values of shoot and apex density, plant growth and flowering frequency in Posidonia oceanica stands at Cabrera Island (Mallorca, Spain). Standard error of the mean is shown within brackets. nd = no data.

\begin{tabular}{|c|c|c|c|c|c|c|c|c|c|}
\hline Bay & Station & $\begin{array}{l}\text { Water } \\
\text { depth (m) }\end{array}$ & $\begin{array}{l}\text { Shoot } \\
\text { density } \\
\text { (shoots } m^{-2} \text { ) }\end{array}$ & $\begin{array}{l}\text { Apex } \\
\text { density } \\
\left(\text { apices } m^{-2} \text { ) }\right.\end{array}$ & $\begin{array}{l}\text { Leaf } \\
\text { production } \\
\text { (number of } \\
\text { leaves shoot } \\
y r^{-1} \text { ) }\end{array}$ & $\begin{array}{l}\text { Vertical } \\
\text { elongation } \\
\text { rate } \\
{ }^{\prime}\left(m m y^{-1}\right)\end{array}$ & $\begin{array}{l}\text { Rhizome } \\
\text { elongation } \\
\text { rate } \\
\left(\text { cm } y r^{-1}\right)\end{array}$ & $\begin{array}{l}\text { Horizontal } \\
\text { branching } \\
\text { rate } \\
\text { (horizontal } \\
\text { branches } y r^{-1} \text { ) }\end{array}$ & $\begin{array}{l}\text { Flowering } \\
\text { frequency } \\
\text { (flowers } \\
\text { shoot }^{-1} y r^{-1} \text { ) }\end{array}$ \\
\hline \multirow[t]{4}{*}{ Santa Maria } & 1 & 7 & $478.14(154.31)$ & $12.38(2.50)$ & $7.36(0.26)$ & $9.43(0.46)$ & $3.84(0.57)$ & 0.025 & 0.0118 \\
\hline & 2 & 13.1 & $287.63(51.17)$ & $13.71(3.29)$ & $7.86(0.27)$ & $10.13(0.42)$ & $3.37(0.61)$ & 0.030 & 0.0009 \\
\hline & 3 & 18 & $287.00(46.29)$ & $5.82(1.54)$ & $7.64(0.13)$ & $5.73(0.23)$ & $4.92(0.27)$ & 0.052 & 0.0026 \\
\hline & 4 & 26.5 & $187.20(20.15)$ & $3.37(0.96)$ & $7.34(0.18)$ & $5.40(0.19)$ & $4.19(0.61)$ & 0.038 & 0.0020 \\
\hline \multirow[t]{8}{*}{ Es Port } & 5 & 2 & $1019.20(60.43)$ & $26.85(4.96)$ & $7.02(0.33)$ & $6.25(0.49)$ & $3.71(0.58)$ & 0.028 & 0.0007 \\
\hline & 6 & 4 & nd & nd & nd & nd & $6.11(0.19)$ & 0.212 & nd \\
\hline & 7 & 5 & $307.33(86.29)$ & $10.57(4.92)$ & $7.11(0.33)$ & $9.35(0.53)$ & $2.98(0.50)$ & 0.045 & 0.0021 \\
\hline & 8 & 10 & $341.71(31.09)$ & $8.53(1.70)$ & $6.64(0.33)$ & $8.67(0.71)$ & $3.13(0.59)$ & 0.069 & 0.0145 \\
\hline & 9 & 15 & $220.00(14.91)$ & $8.91(1.32)$ & $6.50(0.41)$ & $6.54(0.30)$ & $2.60(0.49)$ & 0.045 & 0.0010 \\
\hline & 10 & 17 & $162.00(14.90)$ & $9.90(2.89)$ & $6.93(0.50)$ & $7.71(0.48)$ & $3.89(0.77)$ & 0.045 & 0.0008 \\
\hline & 11 & 20 & $157.71(13.23)$ & $4.73(1.33)$ & $7.20(0.25)$ & $7.73(0.30)$ & $4.04(0.71)$ & 0.062 & 0.0007 \\
\hline & 12 & 25 & $85.00(14.69)$ & $4.00(1.13)$ & $6.76(0.35)$ & $7.35(0.69)$ & $4.61(0.71)$ & 0.030 & 0.0010 \\
\hline
\end{tabular}

actively colonizing (station 6 , Table 2). Branching of the horizontal rhizomes was sparse $\left(<0.25\right.$ branches $\mathrm{yr}^{-1}$ axis $^{-1}$; Table 2), and it was highest at the area with active patch dynamics (Table 2). Flowering was also a rare event in all the stands $\left(<0.015\right.$ flowers shoot ${ }^{-1} \mathrm{yr}^{-1}$; Table 2$)$, and the events were too few to make a comparison among the populations.

Leaf production and vertical rhizome growth showed important interannual variation (Fig. 3). The interannual variability in leaf production rate and vertical growth were positively correlated with each other $(r=0.43, p<0.0001)$. The interannual patterns in leaf production and vertical growth showed some similarity across stands. Flowering events, assessed for all stands pooled together showed considerable interannual differences, with peaks of flowering in the late-1970s, mid-1980s and early-1990s (Fig. 4).

Shoots 2.5-11 years old dominated the meadows, although a few shoots exceeded 25 years of age in most stands (Fig. 5). The rate of shoot recruitment during the year 2000 varied between $<0.009$ and 0.17 ln units $\mathrm{yr}^{-1}$ (Table 3 ) and tended to decline with increasing depth $(r=-0.60, p<$ 0.05 ; Table 3 ). The mortality rate was low (mean $0.10 \pm 0.02$ In units $\mathrm{yr}^{-1}$; Table 3 ), but generally exceeded the recruitment rate (Table 3), indicative of negative net population growth rates. Negative net population growth rates were detected in $55 \%$ of the sites examined (Table 3 ).

The patches developing near the pier of Es Port showed a log-normal size distribution, with a median and modal size of $0.091 \mathrm{~m}^{2}$ and $0.062 \mathrm{~m}^{2}$ respectively, and $90 \%$ of the patches were smaller than $2 \mathrm{~m}^{2}$. Assuming that patch expansion rate has been constant since patch establishment, and that patch expansion rate equalled rhizome elongation rate in the population (Table 2), patch size structure indicates that $66 \%$ of the patches were already present before the implementation of conservation measures in the Park (Fig. 6). The oldest existing patch originated at the end of 19 th century, and since then until 1980 no new patches, surviving to the present, settled in the area (Fig. 6). The results indicated an exponential increase in the area occupied by $P$. oceanica during the last century described by the fitted equation (Fig. 6),

Area colonized $(\%)=10^{-3.96( \pm 0.008)} \times$ Time $(\text { years })^{2.06( \pm 0.004)}$ $r^{2}=0.99 ; n=109$

\section{Changes since protection}

By pooling all estimates from each of the two sites, the annual leaf production rates in Es Port and Santa Maria stands tended to increase, albeit not significantly (t-test, $p>0.05$ ), by $<4 \%$ following regulation of mooring in 1993 in Es Port, when compared with the average leaves annually produced before 1993 (Fig. 7). The vertical growth rate tended to decrease by $8 \%$ in Es Port stands, and declined significantly (t-test, $p<0.05$; Fig. 7) by $20 \%$ in Santa Maria stands after regulation of mooring in the bays. Moreover, flowering has been rare since 1993, being detected in the data only once over this period. The number of patches in the area where recolonization was occurring increased exponentially after 1993 (Fig. 6).

\section{DISCUSSION}

The Posidonia oceanica meadow was much more developed and reached deeper in Santa María Bay than in Es Port. The depth limit at Santa María Bay $(43 \mathrm{~m})$ is the deepest yet reported for this species, indicative of the exceptional transparency of the waters in this bay. The growth of $P$. oceanica in the stands studied showed substantial interannual variability in both Santa María Bay and Es Port, which was not in phase among stations, pointing to local, rather than climatic factors, as the main drivers of the variability observed. Previous research in $P$. oceanica meadows along the Spanish mainland has also demonstrated considerable interannual 


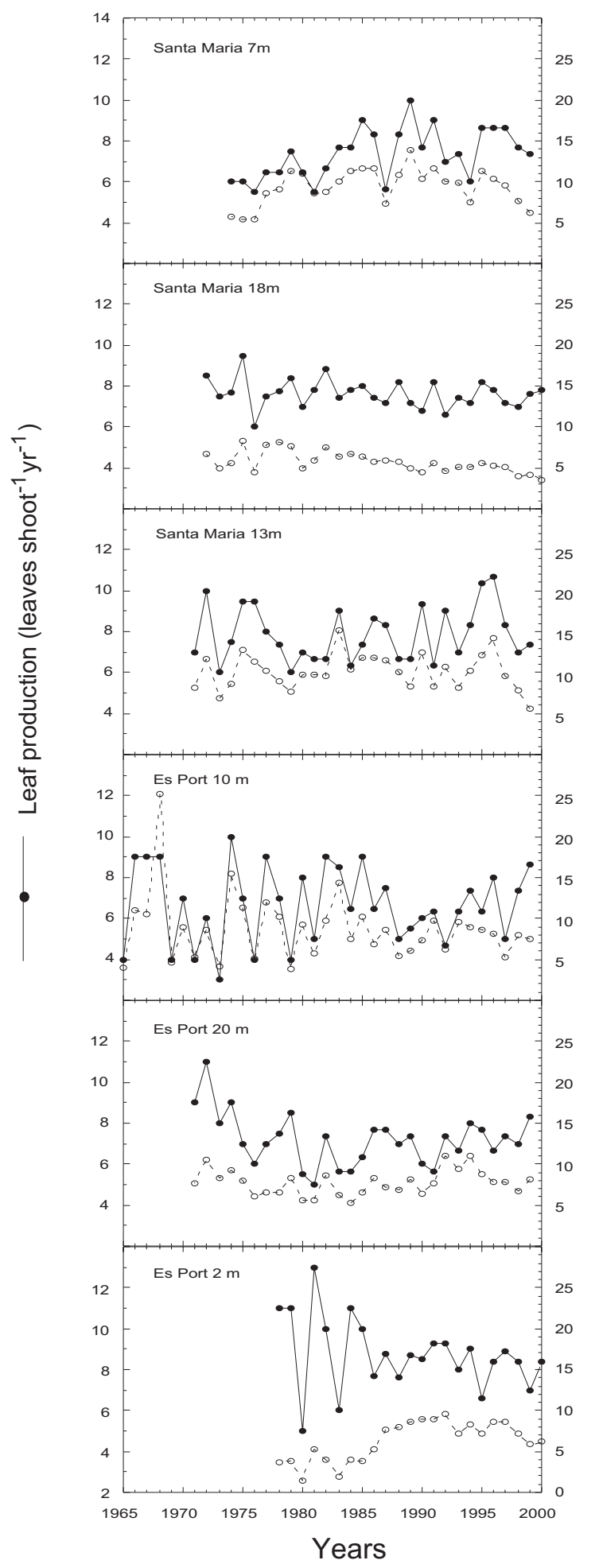

Figure 3 Mean annual leaf production (number of leaves shoot ${ }^{-1}$ $\mathrm{yr}^{-1}$ ) and vertical rhizome growth rate $\left(\mathrm{mm} \mathrm{shoot}^{-1} \mathrm{yr}^{-1}\right)$ in the Posidonia oceanica meadows studied for the last three decades.

growth variability, which was only partially linked to climatic variability (Marbà \& Duarte 1997). Flowering of $P$. oceanica was rather sparse $\left(<3 \%\right.$ of shoots year $\left.{ }^{-1}\right)$, consistent with

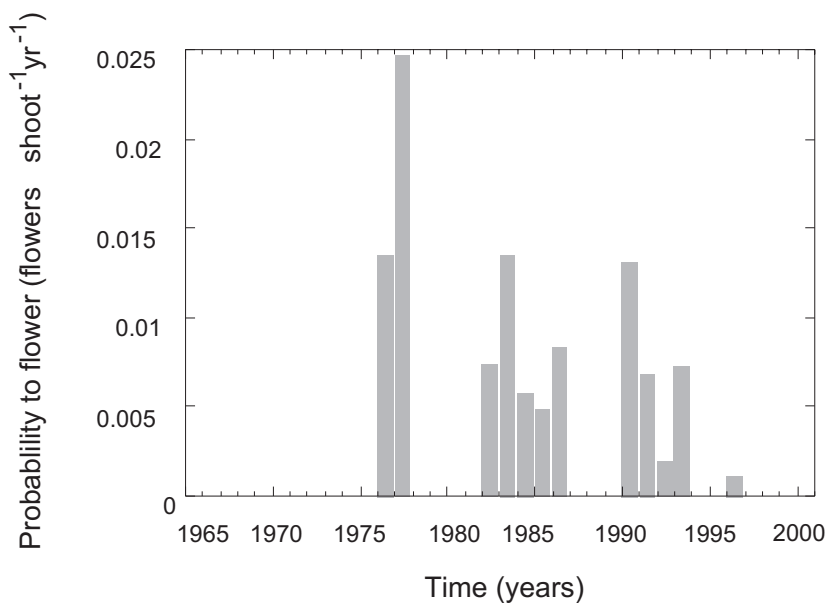

Figure 4 Flowering intensity (inflorescences shoot $\mathrm{t}^{-1} \mathrm{yr}^{-1}$ ) in Posidonia oceanica at Cabrera Island for the last three decades.

previous reports for this species (cf. Pergent \& PergentMartini 1990), and occurred in events separated by about $7-10$ years.

The leaf production of $P$. oceanica shoots tended to increase in both bays following the onset of regulation measures, with this increase being modest $(<5 \%)$ and not statistically significantly. In contrast, the vertical growth of the rhizomes tended to decrease following regulation, with this decrease being greater, and statistically significant, at Santa Maria Bay, where access to visitors is restricted, than at Es Port, where boats are allowed to moor to permanent weights. The reduction in $P$. oceanica vertical growth rate is generally associated with reduced sediment disturbance (Marbà \& Duarte 1997; Manzanera et al. 1998), suggesting that regulation measures have been more effective in preventing sediment disturbance at Santa Maria Bay than at Es Port.

Further evidence of the effectiveness of regulation in improving the status of the $P$. oceanica meadows at Cabrera National Park was the accelerated horizontal growth rate and patch formation rate near the pier at Es Port, where $P$. oceanica was subject to considerable disturbance prior to regulation. Despite the evidence of recovery, the slow horizontal elongation and parsimonious patch formation rates indicate that full recovery of the meadow near the pier will require more than six centuries, consistent with modelling predictions of slow space recolonization by $P$. oceanica (Duarte 1995).

The age structure of the $P$. oceanica meadows revealed important differences in population dynamics among the stands examined, with the median age ranging between 2.5 and 11 years. Indeed, this variability reflected the population dynamics of the species, which showed an important difference between the meadows at Santa Maria Bay and Es Port. While the shallower stands $(<18 \mathrm{~m}$ depth $)$ at Santa Maria Bay were in expansion (i.e. shoot recruitment $>$ mortality), deeper stations tended to be in moderate decline (Table 3). In 

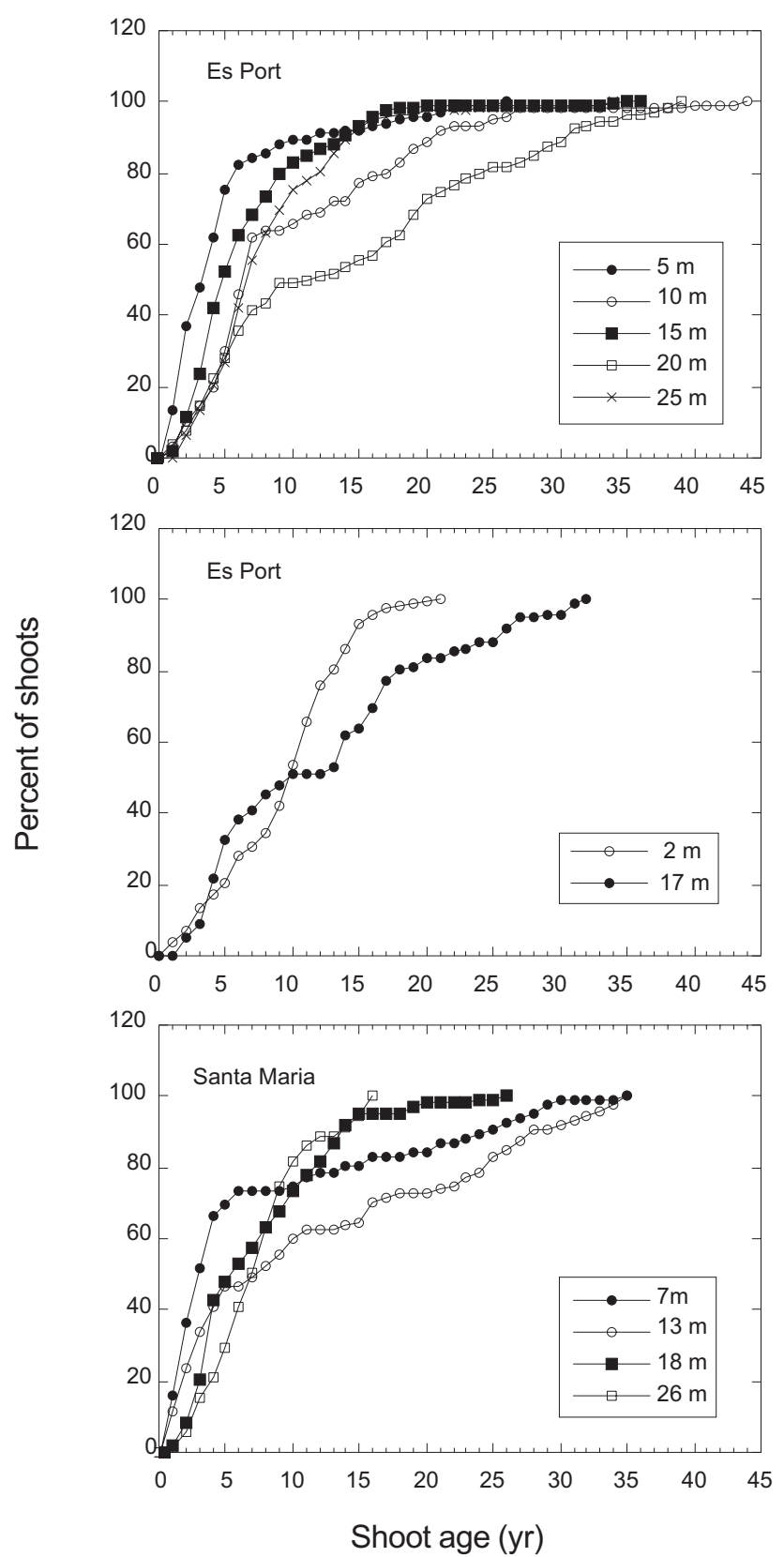

Figure 5 Cumulative age structure of Posidonia oceanica living shoots in the meadows studied at $(a, b)$ Es Port and (c) Santa Maria Bay in Cabrera National Park.

contrast, $60 \%$ of the stands studied below $18 \mathrm{~m}$ depth at Es Port were in decline (Table 3), which was particularly abrupt (net population decline $=0.27 \mathrm{yr}^{-1}$ ) at the shallow station located near the submarine outlet of the treatment plant processing the sewage produced by visitors to the Park. Our results predict that the shoot density at this shallow station will be reduced to half its present level in only three years, consistent with the observation of a substantial area of dead $P$. oceanica matte (i.e. rhizome network) in the periphery of the meadow. Indeed, the P. oceanica stands at Es Port seem to be compromised, and were tending to show a very low shoot recruitment rate, suggesting damage to the sensitive meristems responsible for the clonal growth of the species (Hemminga \& Duarte 2000).

The sediments under the $P$. oceanica meadows at Es Port have been shown to be enriched in organic matter compared to those at Santa Maria (M. Holmer et al., unpublished data 2000), and this organic enrichment has been associated with a reduced oxygen penetration and an increase in the production of sulphides, which are potentially toxic to the plants (Terrados et al. 1999; M. Holmer et al., unpublished data 2000). These results suggest that the anthropogenic organic loading at Es Port is excessive at present. These inputs should derive from sewage produced by the visitors on land (summer average 380 visitors day ${ }^{-1}$ ), and in particular from the visitors staying on the 50 ships moored daily in the bay (about 200 persons day $^{-1}$ ); these ships release their raw sewage directly to the bay waters. In addition to the anthropogenic loading to Es Port Bay, the results from the modelling of water circulation in the bays indicates that the retention rate of materials in Es Port is much higher than that at Santa María Bay. The estimated water residence time at Es Port of 11 days in summer compared to 4 days in Santa María Bay is sufficient to allow the deposition of all of the particle load onto the sediments, assuming an average depth at Es Port of $15 \mathrm{~m}$ and an average sedimentation velocity of $10 \mathrm{~m}$ $\mathrm{day}^{-1}$ (Mann \& Lazier 1991). The increased particle retention associated with the comparatively long water residence time at Es Port compared to Santa Maria, together with the much higher organic loading at Es Port, point to organic enrichment, and the associated oxygen demand and accumulation of phytotoxins in the sediments (M. Holmer et al., unpublished data 2000), as the reason for the fragile status of the $P$. oceanica meadow at Es Port.

In conclusion, the results presented provide evidence of an improved status of $P$. oceanica meadows in response to the implementation of conservation strategies at Cabrera National Park. Whereas the stands protected by quasi-total restriction of visitors show excellent health, those in the area where visitors concentrate could be described as delicate, showing a tendency to decline. This conclusion is particularly of concern given the very slow recolonization rate of $P$. oceanica. The results suggest that the sustainability of public use and the achievement of the conservation of the ecosystems sought by the National Park requires the implementation of alternative strategies directed at either reducing the number of visitors, redistributing the pressure over the islands, or implementing technologies to reduce the organic load to the littoral waters. Hence, the conservation of seagrass meadows through protection measures can only be effective if accompanied by efforts to reduce organic and nutrient inputs to the waters.

\section{ACKNOWLEDGEMENTS}

This research was funded by a grant from the Organismos Autónomo de Parques Nacionales and the M\&Ms project, 
Table 3 Mean values of shoot demography in Posidonia oceanica stands at Cabrera Island (Mallorca, Spain). Standard error of mean values is shown within brackets.

\begin{tabular}{|c|c|c|c|c|c|c|c|c|}
\hline Bay & Station & $\begin{array}{l}\text { Water depth } \\
(m)\end{array}$ & $\begin{array}{l}\text { Median } \\
\text { shoot age } \\
(y r)\end{array}$ & $\begin{array}{l}\text { Maximum } \\
\text { shoot age } \\
(y r)\end{array}$ & $\begin{array}{l}\text { Shoot } \\
\text { recruitment } \\
\text { rate } \\
\left(y r^{-1}\right)\end{array}$ & $\begin{array}{l}\text { Shoot } \\
\text { mortality } \\
\text { rate } \\
\left(y r^{-1}\right)\end{array}$ & $\begin{array}{l}\text { Net } \\
\text { recruitment } \\
\text { rate } \\
\left(y r^{-1}\right)\end{array}$ & $\begin{array}{l}\text { Meadom } \\
\text { status }\end{array}$ \\
\hline \multirow{4}{*}{ Santa Maria } & 1 & 7 & 2.58 & 34.38 & 0.167 & $0.065(0.014)$ & 0.10 & Expansion \\
\hline & 2 & 13.1 & 7.83 & 34.11 & 0.119 & $0.043(0.011)$ & 0.08 & Expansion \\
\hline & 3 & 18 & 5.24 & 25.41 & 0.020 & $0.111(0.015)$ & -0.09 & Decline \\
\hline & 4 & 26.5 & 6.71 & 16.00 & 0.016 & $0.153(0.060)$ & -0.14 & Decline \\
\hline \multirow[t]{7}{*}{ Es Port } & 5 & 2 & 9.63 & 20.33 & 0.057 & $0.331(0.034)$ & -0.27 & Decline \\
\hline & 7 & 5 & 3.09 & 25.30 & 0.155 & $0.122(0.022)$ & 0 & Steady state \\
\hline & 8 & 10 & 6.25 & 43.66 & 0.031 & $0.047(0.016)$ & 0 & Steady state \\
\hline & 9 & 15 & 4.77 & 34.15 & 0.021 & $0.099(0.016)$ & -0.08 & Decline \\
\hline & 10 & 17 & 9.74 & 31.73 & $<0.010$ & $0.054(0.015)$ & $<-0.04$ & Decline \\
\hline & 11 & 20 & 11.18 & 38.60 & 0.039 & $0.034(0.011)$ & 0 & Steady state \\
\hline & 12 & 25 & 6.51 & 33.57 & $<0.009$ & $0.107(0.018)$ & $<-0.10$ & Decline \\
\hline
\end{tabular}

(a)

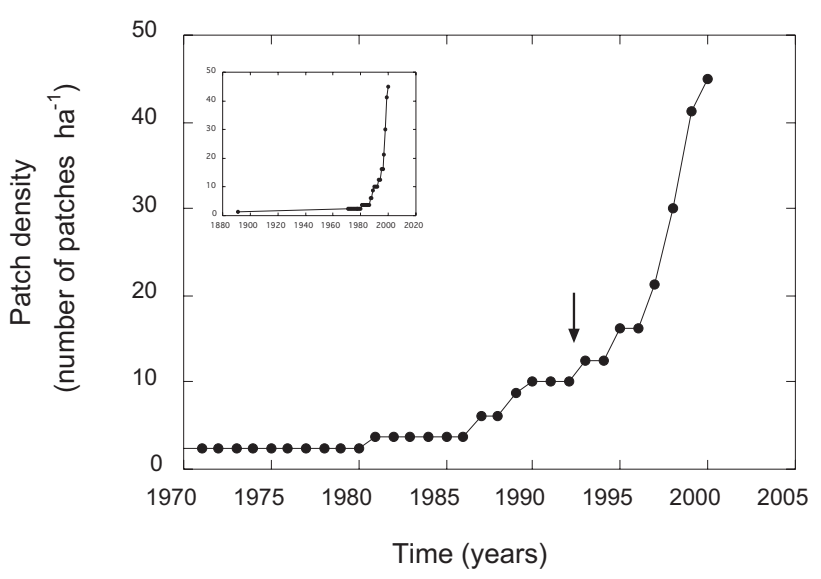

(b)

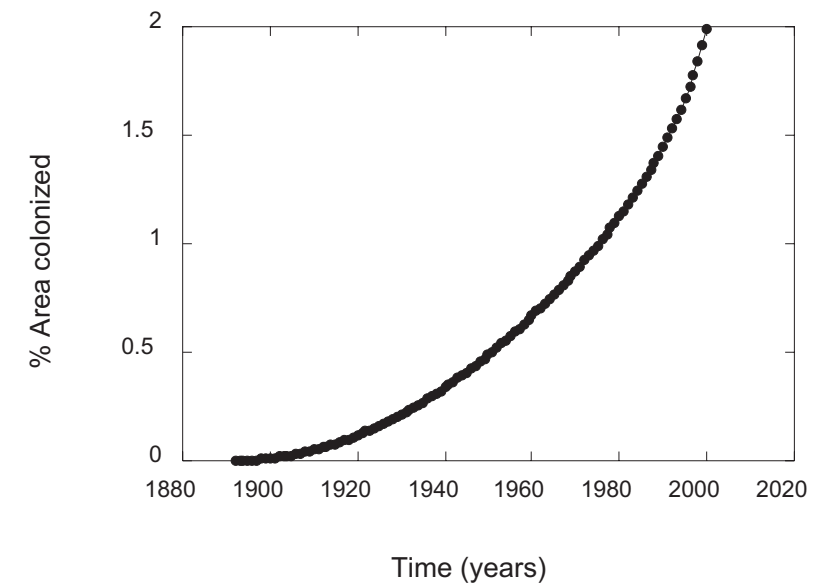

Figure 6 Recovery of a Posidonia oceanica meadow within a 0.08 ha area of Es Port (Cabrera National Park) where active seagrass colonization is occurring. (a) Estimated temporal changes in the number of Posidonia oceanica patches since 1970 (and since1880 in the small panel); the arrow indicates the year when mooring in the Park was regulated. (b) Time course, as percentage occupation of the area covered by Posidonia oceanica in 2000. (a)

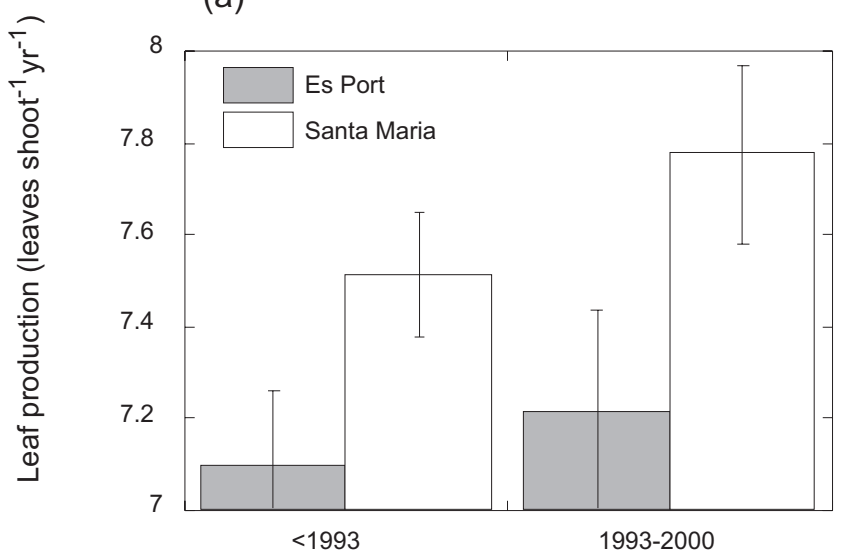

(b)

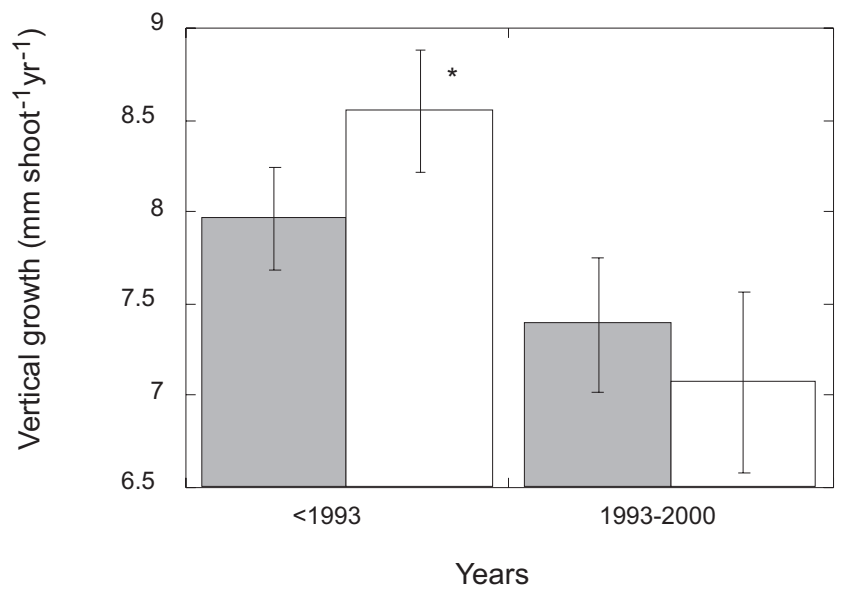

Figure 7 Mean (a) annual leaf production (number of leaves shoot ${ }^{-1} \mathrm{yr}^{-1}$ ) and $(b)$ rhizome vertical growth rate $\left(\mathrm{mm} \mathrm{shoot}^{-1}\right.$ $\mathrm{yr}^{-1}$ ) before and after the 1993 implementation of conservation policies in Santa Maria Bay and Es Port at Cabrera National Park. Bars represent the standard error of the mean. Significant differences ( $\mathrm{t}$ test, $p<0.05$ ) are indicated $(*)$. 
funded by the European Commission (contract \# EVK3CT-2000-00044). We thank J. Moreno and J. Amengual for proposing this research and providing logistic support throughout the study, the Park guards for assistance and friendship during the field campaigns, B. Casas for help in the field and data analysis, J. Llabrés for help with GIS analysis, C. Arrondo, S. Sørensen and J. Terrados for assistance in the field, and two anonymous referees for useful comments.

\section{References}

Ballesteros, E. \& Zabala, M. (1993) El bentos: el marc físic. In: Història natural de l'Arxipèlag de Cabrera, Monografies de la societat d'Història Natural de les Illes Balears 2, ed. J.A. Alcover, E. Ballesteros \& J.J. Fornós, pp. 663-685. Palma de Mallorca, Spain: Editorial Moll-CSIC.

Bethoux, J.P. \& Copin-Móntegut, G. (1986) Biological fixation of atmospheric nitrogen in the Mediterranean Sea. Limnology and Oceanography 31: 1353-1358.

Buia, M.C. \& Mazzella, L. (1991) Reproductive phenology of the Mediterranean seagrasses Posidonia oceanica (L.) Delile, Cymodocea nodosa (Ucria) Aschers., and Zostera noltii Hornem. Aquatic Botany 40: 343-362.

Cancemi, G., De Falco, G. \& Pergent, G. (2000) Impact of a fish farming facility on a Posidonia oceanica meadow. Biologia Marina Mediterranea 7: 341-344.

Chivers, R.C., Emerson, N. \& Burns, D.R. (1990) New acoustic processing for underway surveying. The Hydrographic fournal 56: $8-17$.

Delgado, O., Grau, A., Pou, S., Riera, F., Massuti, C., Zabala, M. \& Ballesteros, E. (1997) Seagrass regression caused by fish cultures in Fornells Bay (Menorca, Western Mediterranean). Oceanologia Acta 20: 557-563.

Duarte, C.M. (1995) Submerged aquatic vegetation in relation to different nutrient regimes. Ophelia 41: 87-112.

Duarte, C.M. (2002) The future of seagrass meadows. Environmental Conservation 29: 192-206.

Duarte, C.M. \& Sand-Jensen, K. (1990) Seagrass colonization: Biomass development and shoot demography in Cymodocea nodosa patches. Marine Ecology Progress Series 67: 97-103.

Duarte, C.M., Marbà, N., Agawin, N., Cebrián, J., Enríquez, S., Fortes, M.D., Gallegos, M.E., Merino, M., Olesen, B., SandJensen, K., Uri, J. \& Vermaat, J. (1994) Reconstruction of seagrass dynamics: age determinations and associated tools for the seagrass ecologist. Marine Ecology Progress Series 107: 195-209.

Erickson, R.O. \& Michelini, F.J. (1957). The Plastochron Index. American Fournal of Botany 44: 297-305.

Francour, P. (1994) Pluriannual analysis of the reserve effect on ichtyofauna in the scandola natural reserve (Corsica, northwestern Mediterranean). Oceanologica Acta 17: 309-317.

Frontera, M., Forteza, V. \& Tomàs, P. (1993) Home i natura: els usos tradicionals del sòl i la pesca. In: Història natural de l'Arxipèlag de Cabrera, Monografies de la societat d'Història Natural de les Illes Balears 2, ed. J.A. Alcover, E. Ballesteros \& J.J. Fornós, pp. 749-762. Palma de Mallorca, Spain: Editorial Moll-CSIC.
Garcia-Rubies, A. \& Zabala, M. (1990) Effects of total fishing prohibition on the rocky assemblages of medes islands reserve (NW Mediterranean). Scientia Marina 54: 317-328.

Hemminga, M.A. \& Duarte, C.M. (2000) Seagrass Ecology. Cambridge, UK: Cambridge University Press: 298 pp.

Lynch, D.R. \& Werner, F.E. (1987) Three-dimensional hydrodynamics of finite elements. Part I: Linearized Harmonic Model. International Fournal for Numerical Methods in Fluids 7: 871-909.

Mann, K.H. \& Lazier, J.R.N. (1991) Dynamics of Marine Ecosystems. Biological-Physical Interactions in the Oceans. Oxford, UK: Blackwell Scientific Publications.

Manzanera, M., Pérez, M. \& Romero, J. (1998) Seagrass mortality due to oversedimentation: an experimental approach. Fournal of Coastal Conservation 4: 67-70.

Marbà, N. \& Duarte, C.M. (1997) Decadal changes in seagrass (Posidonia oceanica) growth and environmental change in the Spanish Mediterranean littoral. Limnology and Oceanography 42: $800-810$.

Marbà, N. \& Duarte, C.M. (1998) Rhizome elongation and seagrass clonal growth. Marine Ecology Progress Series 174: 269-280.

Marbà, N., Duarte, C.M., Cebrián, J., Enríquez, S., Gallegos, M.E., Olesen, B. \& Sand-Jensen, K. (1996) Growth and population dynamics of Posidonia oceanica in the Spanish Mediterranean coast: elucidating seagrass decline. Marine Ecology Progress Series 137: 203-213.

Meinesz, A. \& Lefèvre, J.R. (1984) Régénération d'un herbier de Posidonia oceanica quarante années après sa destruction par une bombe dans la rade de Villefranche (Alpes-Maritimes, France). In: International Workshop on Posidonia oceanica Beds, ed. C.F. Boudouresque, J. de Grissac \& J. Olivier, pp. 39-44. Posidonie, Marseille, France: GIS Marseille.

Orlowski, A. (1984) Application of multiple echo energy measurements for evaluation of sea bottom type. Oceanologia 19: 61-78.

Peirano, A. \& Bianchii, N.C. (1995) Decline of the seagrass Posidonia oceanica in response to environmental disturbance: a simulation-like approach of Liguria (NW Mediterranean Sea). In: Proceedings for the 30th European Marine Biological Symposium, ed. L.E. Hawkins, S. Hutchinson, A.C. Jensen, M. Sheader \& J.A. Williams, pp. 87-95. Southampton, UK: University of Southampton.

Pergent, G., \& Pergent-Martini, C. (1990) Some applications of lepidochronological analysis in the seagrass Posidonia oceanica. Botanica Marina 33: 299-310.

Peterson, J.B. \& Fourqurean, J.W. (2001) Large-scale patterns in seagrass (Thalassia testudinum) demographics in south Florida. Limnology and Oceanography 46: 1077-1099.

Short, F.T. \& Duarte, C.M. (2001) Methods for the measurement of seagrass growth and production. In: Global Seagrass Research Methods, ed. F.T. Short \& R.G. Coles, pp. 155-182. Amsterdam, the Netherlands: Elsevier.

Terrados, J., Duarte, C.M., Kamp-Nielsen, L., Borum, J., Agawin, N.S.R., Fortes, M.D., Gacia, E., Lacap , D., Lubanski, M. \& Greve, T. (1999) Are seagrass growth and survival affected by reducing conditions in the sediment? Aquatic Botany 65: 175-97.

UNEP (1999) State and pressures of the marine and coastal Mediterranean environment. European Environmental Agency, Office for Official Publications of the European Communities, Luxembourg. 